\title{
Winds of change and rural multifunctionality: study on social representations of farmers in the extreme south of Brazil ${ }^{1}$
}

\author{
Ventos da mudança e multifuncionalidade rural: estudo sobre \\ representações sociais de agricultores no extremo sul do Brasil

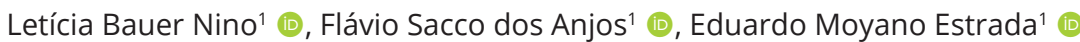

1Programa de Pós-graduação em Sistemas de Produção Agrícola Familiar, Universidade Federal de Pelotas (UFPel), Pelotas (RS), Brasil.E-mails: leticiabnino@hotmail.com; saccodosanjos@gmail.com; emoyano@iesa.csic.es.

\begin{abstract}
How to cite: Nino, L. B., Anjos, F. S., \& Moyano Estrada, E. (2022). Winds of change and rural multifunctionality: study on social representations of farmers in the extreme south of Brazil. Revista de Economia e Sociologia Rural, 60(3), e238489. https://doi.org/10.1590/1806-9479.2021.238489
\end{abstract}

\begin{abstract}
Inaugurated in 2011, the Campos Neutrais Wind Complex was considered at the time the largest wind farm in Latin America, spread over the municipalities of Santa Vitória do Palmar, Rio Grande, and Chuí, on the border with Uruguay. This region stands out for the production of irrigated rice and extensive cattle raising. The wind turbines were installed predominantly in medium and large establishments, whose owners signed contracts with the energy companies. The reconciliation between energy generation and agricultural production reflects the modern concept of multifunctionality. Many producers see the environmental issue as antagonistic to their immediate interests. However, a new scenario appears at the moment when they start earning great income from the generation of energy. The objective of the research was to assess whether there were signs of changes in perception and behavior among the producers who joined the project. The research was carried out between 2016 and 2017 with several actors through in-depth interviews. The theory of social representations was the instrument used in the analysis of the testimonies. The main conclusion is that the new scenario has not changed the view of producers in the face of environmental issues, which mostly remain attached to the so-called agrarian fundamentalism.
\end{abstract}

Keywords: wind energy, perceptions, rurality, sustainability.

Resumo: Inaugurado em 2011, o Complexo Eólico Campos Neutrais foi considerado, à época, o maior parque eólico da América Latina, distribuindo-se pelos municípios de Santa Vitória do Palmar, Rio Grande e Chuí, na fronteira com o Uruguai. Tal região se destaca pela produção de arroz irrigado e criação extensiva de gado. Os aerogeradores foram instalados predominantemente em médios e grandes estabelecimentos cujos proprietários firmaram contratos com empresas de energia. A conciliação entre a geração de energia e a produção agropecuária reflete o moderno conceito de multifuncionalidade. Muitos produtores veem a questão ambiental de forma antagônica aos seus interesses imediatos. Todavia, um novo cenário surge no momento em que passam a auferir grandes rendas com a geração de energia. O objetivo da pesquisa foi avaliar se havia indícios de mudanças de percepção e comportamento entre os produtores que aderiram ao projeto. A pesquisa se desenvolveu entre 2016 e 2017, com diversos atores, por meio da realização de entrevistas em profundidade. A teoria das representações sociais foi o instrumento utilizado na análise dos depoimentos. A principal conclusão é que o novo cenário não alterou a visão dos produtores ante as questões ambientais, os quais, majoritariamente, seguem aferrados ao chamado fundamentalismo agrário.

Palavras-chave: energia eólica, percepções, ruralidade, sustentabilidade.

\footnotetext{
This article was conceived thanks to the support of several institutions. We are grateful to CAPES for the granting of a sandwich doctoral scholarship to the first author, carried out in 2017 at the Institute for Advanced Social Studies, linked to the Superior Council for Scientific Research in Spain (IESA-CSIC), as well as for the granting of a Visiting Professor scholarship Senior (Process n 88887.363956 / 2019-00) to the second author in the period 2019-2020, within the framework of the CAPES-PRINT-UFPel Program project. The acknowledgment extends to CNPq for the granting of a research productivity scholarship (Process No. 305086 / 2018-9), to the second author, as well as to IESA-CSIC, which kindly hosted both scientific missions.
} 


\section{Introduction}

The question of energy is a hotly debated topic in contemporary societies. Energy production and consumption are, on the one hand, a central theme in the field of innovation, but, on the other, it is also controversial, particularly when it comes to creating reliable strategies for transitioning towards a more sustainable energy model.

It is an obvious fact that, as the population grows and increases its level of welfare, the energy demand increases, while there is always a limited availability of natural resources. This fact leads to the need to extend the reference framework for our socioeconomic model, based, as we know, on the unlimited use of raw materials and natural resources. This model is increasingly questionable, and is, therefore, one of the reasons for the re-reading of some authors, such as Georgescu-Roegen (2012), who for several years have been denouncing the misunderstandings of neoclassical economics and stressing the need to introduce ethical considerations into the economy and situate ecosystem limits at the heart of the decisions of economic agents, whether these are public or private. Important works such as Abramovay (2012) and Daly (1989), identified with the so-called ecological economy, also highlight these imperatives.

In Brazil, the proportion of renewable energies in relation to general energy production is $87.8 \%$. Official data from Brazil (Brasil, 2018) indicate that, in June 2018, in the period of one year, hydro generation registered an increase of $3.5 \%$ in installed capacity, reaching $102,228 \mathrm{MW}$. The wind source grew by $20.7 \%$ and corresponds to $12,931 \mathrm{MW}$. The biomass had an elevation of $3.7 \%$ and totals $14,657 \mathrm{MW}$. Solar, despite the smaller total volume, grew $577 \%$ and reached 1,602 MW.

Recent data indicate that Brazil ranks $8^{\text {th }}$ among the largest wind power generators in the world. In the context of its 26 Federative Units, Rio Grande do Sul, the southernmost state in the country, ranks third in terms of the installed capacity of its wind farms (Agência Brasil, 2018).

This article aims to analyse possible changes in attitude and behaviour of farmers in the "Campos Neutrais" (Neutral Fields) area in the Brazilian state of Rio Grande do Sul with regard to environmental issues in the context of wind-energy production on land formerly used for agricultural production. It also aims to evaluate the perception of the functions that the territory can perform in addition to agricultural production.

This is based on the results of a study developed in the region known as "Campos Neutrais" located in the extreme south of Rio Grande do Sul state. It is a large area that extends along the border of Brazil and Uruguay, just inside one of the most unique ecosystems in Latin America (the Pampa Biome), which was traditionally dedicated to agricultural and livestock production.

The study area was chosen because a large number of wind turbines have been installed inside the small, medium, and large farms via contracts signed between the farmers and the companies operating in this market (domestic and/or foreign). In exchange for ceding part of their land, the owners receive a monthly income for a set period, usually 20 years (extendable).

The new economic and social reality generated by the installation of wind farms on lands traditionally used for agricultural and livestock production can be seen as the material expression of the "Rural multifunctionality", understood as a new discourse, where other functions are attributed in addition to 'stricto sensu' agricultural production. This means that the debate on the multifunctionality of the rural area advocates that agriculture no longer represents the only and exclusive economic activity carried out in rural areas.

In this new reality, rural territories assume other functions beyond the production of food, fibres, and raw materials, such as energy production, in this case, wind energy. For farmers, this reality represents a completely new situation, because it gives them the possibility of 
obtaining stable economic income that has nothing to do with the income (normally unstable) from agricultural activity.

This could imply an important change in the mentality of farmers, who traditionally regard the discourse on protecting the external environment as a threat to their freedom to use natural resources fully and without restrictions. Some rural sociology studies (Silvasti, 2003; Burton, 2004) have analysed the attitudes and perceptions of farmers on issues relating to the environment, showing the existence of antagonism between productivist and conservationist positions, even suggesting the terms "good" and "bad" farmers (Naylor et al., 2018).

However, focusing our attention on the case of Brazil and, more specifically, on the production of wind energy on agricultural land, we can ask ourselves what happens when the agricultural establishment becomes the territorial base for the production of renewable energy. Do the owners' framework references change when they assume a new function, that provides a revenue unrelated to agricultural production?

This is the central question guiding this research, and we have answered it using the information gathered in a programme of interviews with various social and economic stakeholders, and analysing the data with the tools provided by the theory of social representations, an approach whose main features we describe in the following section.

\section{Theoretical foundation}

\section{Social representations as a theoretical framework}

This article is based on the results of a study developed in the region known as "Campos Neutrais" (Neutral Fields), located in the extreme south of Rio Grande do Sul state. It is a large area that extends along the border of Brazil and Uruguay, just inside one of the most unique ecosystems in Latin America (the Pampa Biome), which was traditionally dedicated to agricultural and livestock production.

The exploratory phase of the research had shown evidence that the installation of the wind complex would bring about several changes. Some of them are clearly noticeable, as is the case of the buildings that erected the wind turbines and other structures that substantially modified the landscape. The expectation of improving living conditions for local people was another aspect that gained importance in the speech of the first interviewees.

The incorporation of environmental rights into the Brazilian legal system faces resistance from some economic sectors, and especially within the agricultural sector. The Brazilian Constitution (Brasil, 1988) establishes that the right to use and enjoy a healthy environment belongs to everyone, and this is recognised as a public asset essential for the population's quality of life.

However, it is difficult for farmers to assimilate this, since many agricultural practices, some of which are incompatible with the current principles of sustainable development, are embedded in the rural culture and have been handed down over many generations. In this sense, the concept of "habitus" (Bourdieu, 1972) is very appropriate for understanding how individuals, in this case, agricultural landowners and ranchers, perceive the social world and react to it, both as a social and a socio-political category.

We have therefore considered the theoretical approach of social representations useful for our study, as it makes the invisible visible, probing the meanings, beliefs, and values expressed through language (Moscovici, 2009). In accordance with Pereira \& Almeida (2015, p. 129), "The theoretical character of social representations assists in the construction of the research object 
and the scientific explanation of the phenomena through interpretative analyses". Sacco dos Anjos \& Caldas (2012, p. 4) highlight an important aspect when considering that:

It is in the founding work of modern sociology, Émile Durkheim's (1968) "The rules of sociological method", written in 1895, that we find the first allusions to the issue of representation in the distinction drawn between "individual" and "collective" representations. However, as Duveen (2010, p. 13) warns, the effort to raise sociology as an autonomous science-led Durkheim to propose a radical separation between these two forms of representation, with the former falling into the field of psychology and the latter coming to constitute the object of sociology (highlighted in the original)

Minayo (1995, p. 90) recalled that the term "social representations" referred to those "categories of thought through which a given society develops and expresses its reality". In general, the social representations must be understood as shared mental processes or phenomena, through which people organise their lives. Specifically, it can be said that social representations guide the decisions and attitudes of individuals in their daily lives, offering a system of values that guides them in their daily work.

According to Duveen (2009, p. 16), citing Moscovici, the theory of social representations is useful for analysing "the processes in which innovation and change, as well as conservation and preservation, are part of social life". For Moscovici (2009, p. 40), what is really important is to analyse how social representations can influence the behaviour of individuals immersed in a broad process of social, economic, and cultural change (Moscovici, 2009, p. 54).

In our research that framework was employed to understand how farmers and ranchers assimilate changes in their social and economic environment when new functions are attributed to rural areas that affect them directly, as is the case with the generation of renewable energies on their farms.

The installation of wind turbines in rural areas, within establishments traditionally used for agricultural production, represented a novelty for Campos Neutrais. We start from the premise that this event translates, in a very clear way, the principles that support the concept of multifunctionality referred to in several studies, such as Moyano \& Garrido Fernández (2007), Reig-Martínez (2007), and Sacco dos Anjos \& Caldas (2012)

It is, however, a diffuse transition process and, at the same time, confusing and contradictory, which explains the difficulties farmers have in digesting it (Dufour et al., 2007; Knickel \& Henting, 2000; Wheeler, 2016). For the purposes pursued by this article, it is important to examine the debate underlying these principles, a task that we are dedicated to following.

\section{Multifunctionality}

If the idea of sustainability was imposed in the 1980s and 1990s as the backbone of public policies in the agricultural and rural areas of Europe and as a mandatory point of social research agendas, in the first five years of the new millennium, multifunctionality has become "a concept assumed by all and used for different purposes" (Moyano \& Garrido Fernández, 2007, p. 2).

For some scholars (Atance \& Tió, 2000, p. 30) it would be nothing more than "a new word for an old concept", which leads to the recognition that agriculture exercises a series of functions that extrapolate the simple production of raw materials, fibers, and food. The production of renewable energies (wind, photovoltaic), as in the case that will be examined in the extreme south of Brazil, would not be more than one of the manifestations of this concept, or what is called an agro-environmental function.

However, agro-livestock activities also generate environmental liabilities, which negatively affect the image of rural producers in contemporary societies, especially with the changes 
introduced by the green revolution (intensive use of chemical fertilizers and pesticides). Several studies (Díez Patier \& Trueba Herranz, 2007; Moyano \& Paniagua, 1998; Garrido Fernandez, 1999) agree that agriculture enjoyed a status of environmental exceptionality, which means that for many years it was seen as a non-polluting activity.

In the international context, the entry into the scene of multifunctionality has not been exempt from strong controversy. The term appears for the first time at the United Nations Conference for the environment and development - Rio 92 - also driven by the successive rounds of negotiations within the World Trade Organization, circumstances that put defenders and detractors of multifunctionality in opposing camps.

The first group was basically formed by the countries of the European Union, interested in protecting direct and indirect support to their agricultural systems, while the second group corresponded to countries interested in expanding world trade. The second group included countries such as Brazil, which jointly argued that direct aid was responsible for distorting the price of agricultural products.

At the European level, successive reforms of the Common Agrarian Policy (1992, 2000, 2003) indicated the gradual incorporation of this concept, which includes an agrarian and a rural significance. The first "is used, in effect, to justify aid to agriculture, but also to support a new legitimacy of the profession of the farmer." The second meaning is activated to support "development programs in the multiplicity of functions performed by rural spaces, from an integral conception of their potential" (Moyano \& Garrido Fernández, 2007, p. 2).

But, one can not disregard the ambivalent nature of this concept. For Reig-Martínez (2007), it was never evident if it was about the multifunctionality of agriculture (as a productive sector) or of the rural areas themselves as a more territory-centered notion ${ }^{2}$. On the other hand, it has not always been clear, from the prism of those who studied the subject, whether they did it from a positive approach or under the aegis of a normative approach.

The positive approach is based on the principle that multifunctionality is a characteristic of the agrarian production processes, based on the economic aspect. From the normative point of view, the multifunctionality of agriculture reflects the plurality of objectives set by society concerning the social, economic, and environmental functions of agriculture.

But there is no doubt that the multifunctionality concept arises from the moment that the development model adopted by European agriculture is questioned, be it about the technical model adopted, the territory intervention, the role of public action, or decisions about what to produce (Verges, 2013, p. 363).

The last CAP (Common Agricultural Policy) reform³, corresponding to the period 2014-2020, was marked by the total decoupling of direct aid to farmers. According to Moyano (2013, p. 43), the Ciolos Reform made "direct payments stop being guided by a productivist logic to be guided by territorial criteria". To a large extent, it frames the possibility of compromising from a typically sectoral orientation, which has dominated the CAP since its inception, up to a territorial or spatial orientation.

In particular, the growing knowledge of the complexity of rural development processes requires the adoption of a multidisciplinary and holistic approach by the researcher, who must recognize the multiple connections that this concept encompasses. One can not disregard the fact that multifunctionality implies a new narrative that is imposed both from the political and the epistemological prism. In this sense:

2 On this aspect, see also Marsden \& Sonnino (2008).

${ }^{3}$ Study conducted by Lowe et al. (2002) addresses this issue. This work examines the key new discretionary features of the Common Agricultural Policy (CAP) after the Agenda 2000 reforms. 
The transfer of discourse in favor of agricultural modernization to the discourse of multifunctionality establishes, after all, a true water divider, not only as an expression of a certain pattern of development but as one of the keys interpretative that allows us to understand the extension of the transformations operated in the field of perceptions of meanings (Sacco dos Anjos \& Caldas, 2012, p. 8, bold in the original).

In the Latin American case, two general orientations are perceived in relation to the theme of multifunctionality. On the one hand, those who argue that this is a debate that is of interest only to the countries of Europe, so that multifunctionality would be nothing more than an "unattainable myth" (Segrelles-Serrano, 2007). On the other side are those who value this concept as very positive and an inspiring source for thinking about policies that recognize the multiple functions of natural spaces, both for agricultural and non-agricultural purposes.

This means as Abramovay (2012) warns, that rurality should be understood as a value for contemporary societies, capable of providing a set of goods, services, and functions that are fundamental for the civilization of the 21st century.

For Cazella et al. (2009), territories are usually considered to be privileged units of expression of the multifunctionality of agriculture to be taken into account in the definition of public policies, especially with regard to family farming.

However, it is important to mention that the multiple functions of nature and rural spaces, in addition to stricto sensu agricultural production, are exercised by different social forms of production, and are therefore not an exclusive mission of a specific sector or group. The fact is that the environmental issue is an issue that affects all individuals (Rémy, 2004).

Modern exploitation does not produce quantity, but one that is based on diversity and quality of processes, especially when we are living the transition from a volume economy to a value economy (Bueno \& Aguilar Criado, 2003). But are our farmers aware of what this Copernican turn implies in their daily practices and tasks?

\section{Methodology}

The central objective of this article, as explained above, is to analyze a possible change in the attitude and behavior of farmers in the "Campos Neutrais" in relation to environmental issues in the context of the production of wind energy on land previously used exclusively for agricultural production.

At the same time, an attempt was made to assess the perception of the functions that the territory can play in addition to agricultural production. It is noteworthy that the effort to define a spatial profile influenced the choice of the case study method. The scope of the study corresponds to the region where the Campos Neutrais Wind Complex was located, located in the extreme south of Rio Grande do Sul.

In presenting the virtues of the Case Study method, Yin emphasizes its application when one wishes to understand complex social phenomena. Furthermore,

\footnotetext{
[...] the case study allows an investigation that tries to preserve the holistic and significant characteristics of real-life events - such as individual life cycles, organizational and administrative processes, changes in urban regions, international relations, and the maturing of some sectors (Yin, 2001, p. 21).
}

Our case study is based on material gathered in 45 interviews conducted in 2016 and 2017. These interviews were part of a larger project and were given to various social stakeholders linked to wind power generation projects in the area "Campos Neutrais" (Rio Grande do Sul), including farmers (30), specialists from companies (three), managers of public institutions 
(seven), experts in the environmental area (two), and representatives of trade unions and agricultural associations (three).

In this article, for practical reasons, we fundamentally explore the point of view of farmers. The purpose of the interview program was to analyze the opinion of agricultural producers who signed contracts for the production of wind energy and who installed wind turbines on their properties.

The interviews lasted an average of approximately 90 minutes and followed a script containing open and/or closed questions. The testimonies of the interviewees were transcribed (verbatim), to form part of a database organised using specific software ( $N$ Vivo) and were analysed through qualitative techniques. The information was examined through the construction of two broad categories.

The first includes the reasons cited by landowners for signing the corresponding contract with companies from the wind energy sector. It also includes the issue of reconciling energy production with the traditional agricultural character of rural areas, as well as their feelings about receiving an income that is completely detached from farming. The second category aims to identify evidence of a new environmental awareness in the minds of the interviewed farmers. The focus of the interviews was, therefore, to analyse the social representations of farmers on the "environmental issue" during a new scenario in which they are inserted as indirect participants in the generation of clean energy, but also as direct beneficiaries of this process.

The selection of the sample reflected the diversity of producers in the region; both from the point of view of the size of their properties, as well as the time elapsed since the signing of the contracts with the companies. The wind companies operating in the area have provided us with information about the farms and owners. The interviewed producers had areas between 20 and 2,500 hectares, that is, from family establishments to large farms based on the employment of wage labour.

Table 1 shows the diversity of producers that integrated the sample from the point of view of the age of the owners, the size of the properties, the number of wind turbines installed on the properties, and the character (family or non-family) of the establishments. The average age of the respondents corresponds to 57.8 years.

There is great variation in relation to the size of the properties of our interviewees, as well as the number of wind turbines built inside. Thus, while some establishments have only one wind turbine, others have 33 of this equipment. This means that, at the time of the interviews, some producers earned an annual income of approximately $R \$ 12,000$, while others earned almost $R \$ 400,000$. At last but, not least, only two establishments are classified as family farming.

\section{Results and discussion}

\section{"Campos Neutrais", as a geographical area}

According to Amaral (1972), the "Campos Neutrais" region refers back to the period of European colonisation, and disputes between the two Iberian crowns for control of the Río de la Plata estuary, an enormous area that is now divided between Brazil, Argentina, and Uruguay. With the signing of the San Ildefonso Treaty (1777), Spain and Portugal established an exclusion zone, comprising a strip of uninhabited land, that today is part of Rio Grande do Sul state, in the extreme south of Brazil. The agreement was that it would not be occupied by any of the Iberian crowns. Hence the name "Campos Neutrais" designates this geographical area. 
Table 1. Age of holders of establishments interviewed, size of establishments (hectares), number of wind turbines, and character of establishments (familiar or unfamiliar).

\begin{tabular}{ccccc} 
Number & $\begin{array}{c}\text { Age of holders } \\
\text { (years old) }\end{array}$ & $\begin{array}{c}\text { Size } \\
\text { (ha) }\end{array}$ & $\begin{array}{c}\text { Number of } \\
\text { Wind-turbines }\end{array}$ & $\begin{array}{c}\text { Character (Familiar or } \\
\text { Unfamiliar) }\end{array}$ \\
A1 & 54 & 120 & 09 & Unfamiliar \\
A2 & 61 & 2.500 & 27 & Unfamiliar \\
A3 & 54 & 680 & 09 & Unfamiliar \\
A4 & 73 & 800 & 13 & Unfamiliar \\
A5 & 46 & 839 & 15 & Unfamiliar \\
A6 & 65 & 142 & 04 & Familiar \\
A7 & 33 & 470 & 18 & Unfamiliar \\
A8 & 54 & 78 & 05 & Unfamiliar \\
A9 & 55 & 120 & 01 & Familiar \\
A10 & 55 & 20 & 01 & Unfamiliar \\
A11 & 61 & 530 & 21 & Unfamiliar \\
A12 & 63 & 120 & 03 & Unfamiliar \\
A13 & 56 & 2.000 & 05 & Unfamiliar \\
A14 & 69 & 200 & 07 & Unfamiliar \\
A15 & 53 & 1.000 & 23 & Unfamiliar \\
A16 & 72 & 1.800 & 33 & \\
\hline
\end{tabular}

Source: Field Research (2018).

Before the incursions of Spain and Portugal in the $16^{\text {th }}$ century, space nowadays known as "Campos Neutrais" was occupied by Native American peoples, such as the Minuane, Charrua, and Arachan nations. With the Portuguese colonisation, the system of settlements known as sesmarias was expanded. This system granted large areas of land, by the Lusitanian Crown, to people loyal to the empire, and by the year of Brazilian independence (1822), it was already widespread in the area.

This system had a twofold objective: on the one hand, to encourage livestock production; and, on the other, to form a frontier in the region bordering the countries of the Rio de la Plata. In this way, a system of large estancias, or ranches was formed. These constituted the cultural and symbolic universe of the gaucho, the centaur of the Pampa, as found in famous works of literature, such as "Martín Fierro", a narrative poem written by José Hernández in 1872.

The "Campos Neutrais" area (Figure 1) extends from the "Taim wetlands" to the Chuy Stream at the extreme tip of Brazil. It is a region of vast plains, rich in biodiversity, both animal and vegetable, and has abundant water resources, with large lakes (Mirim and Mangueira). It is a protected biosphere reserve, given that many migratory birds coming from southern Spain (specifically Doñana National Park), as well as other parts of the planet, make this area one of their mandatory stops.

Historically, livestock (cattle, sheep, and horses) has been one of the main vocations of the region, especially developed in large areas of land (estancias) under the extensive regime. However, at the beginning of the 20th century, rice culture was introduced as part of a modernization process that would intensify during the "green revolution" (1970s), bringing significant changes in agricultural practices through the introduction of intensive mechanization, improved seeds, and agrochemicals.

As a result of the process of agricultural modernisation, the "Campos Neutrais" region became one of the most important rice-producing areas. In fact, Rio Grande do Sul State is now responsible for 75 percent of all rice produced in Brazil. 


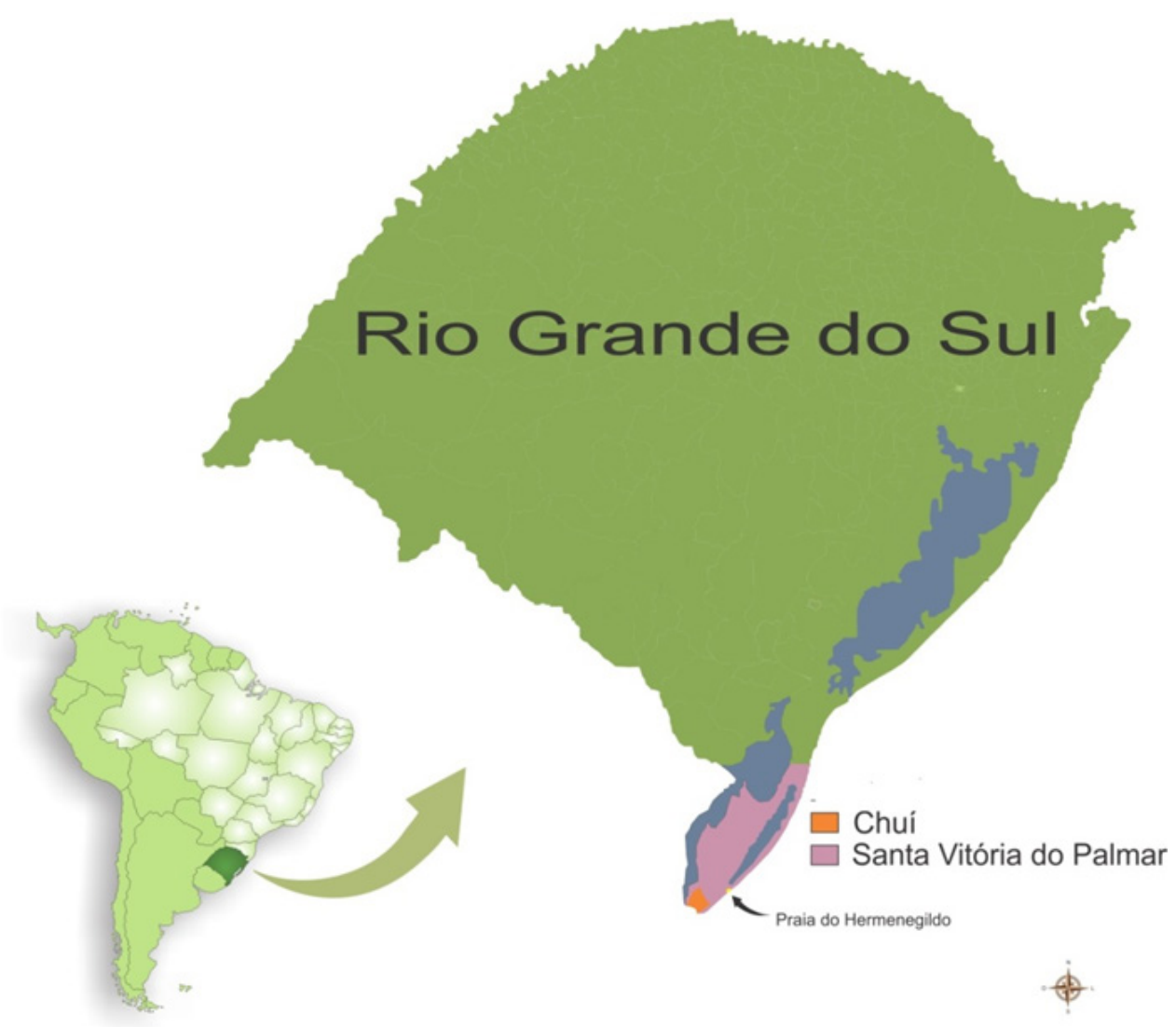

Figure 1: Illustrative map of Rio Grande do Sul with the location of the municipalities of Santa Vitória do Palmar, Chuy, and Hermenegildo Beach. Source: Authors' elaboration

\section{The "Campos Neutrais" Wind-power Complex}

In Brazil, the expansion of wind power has arisen as an effort to diversify its energy sources and to be less vulnerable to sectorial crises and/or climate problems, given the effects that rainfall has on the operation of hydroelectric plants.

In 2002, the Brazilian government launched the Incentive Programme for Alternative Sources of Electrical (PROINFA), the objective of which was to expand renewable energy production (Brasil, 2002).

The projects related to wind energy were implemented through public-private partnerships, based on public concessions to companies through 20-year contracts. The first concession was granted in 2009 and mainly affected the northeastern states. The southern regions of Brazil would see the implementation of PROINFA a little later, but the pace of its growth was greatly affected by the economic and political crisis that began in 2014.

The "Campos Neutrais" Wind Complex gathers Geribatu, Chuy, and Hermenegildo wind farms. Together they are responsible for generating 583 megawatts (MW) of nameplate capacity, sufficient to meet the consumption needs of 3.3 million inhabitants. This project is led by Eletrosul (a public company linked to the Ministry of Mines and Energy, Brazil) and involves private partners, whose investment funds, eminently Brazilian in origin, totalled $\mathrm{R} \$ 3.5$ billion.

While in the northeastern states the implementation of wind energy projects took place through the purchase or expropriation of land from private individuals, in the case of the 
"Campos Neutrais" Wind Complex, the process was different, established through lease contracts on privately owned land used for agriculture and livestock.

After the initial studies and the implementation of some pilot projects, the transactions between companies and landowners in "Campos Neutrais" underwent two stages, with two types of economic earnings

The first stage took place during the construction of the infrastructure for the Wind-energy Complex, at which time landowners received an income equivalent to the value of one and a half harvests of the most commercially valued type of rice. The payment was justified as a way of compensating farmers for any losses caused by a possible reduction in the agricultural productivity of their farms, or as a way of compensating them for any damage and/or inconvenience caused.

The second stage took place when the wind complex went into operation. Landowners were paid an amount for energy production, receiving the equivalent of 1.8 percent of the turnover from the sales of the energy produced by the wind farm. The calculations by the Wind-energy Complex companies for setting the amounts to pay to rural landowners took into account the surface leased in each property and not the number of wind turbines installed.

The implementation of this great project changed the face of the region and the behaviour of people and institutions. There was an atmosphere of optimism, but also mistrust. The essential focus of the research was to find out if the producers changed their view on environmental issues from the moment became part of a renewable energy generation process. In other words, we wanted to know if, in the face of the new reality, their perception and attitudes towards natural resources changed.

\section{Wind-energy and the winds of cultural change mutation}

It is not easy to reveal the nature of the farmers' social representations, let alone identify supposed changes in their perceptions and attitudes when they are attributed a new role in society, such as producing energy on their land.

And it is not easy for two reasons: (i) because it is an evaluative position that is usually hidden in the world of meanings. It was necessary to interpret the symbolic systems that are implicit in the speeches of the actors involved, in order to make them intelligible as a social practice. In these terms, it is important to make visible and invisible unveiled, as well as what has been said and what has not been said and which is behind the discourse conveyed by social actors. In addition, we must think that (ii) we are facing a complex issue that requires adequate heuristic tools.

The analysis of the interviews showed that, before the producers joined the project related to the "Campos Neutrais" Wind Complex, there was a great deal of uncertainty and mistrust, both from the producers themselves and from most local institutions (unions, city hall, associations, etc.). It is important to keep in mind that this was something unusual in a region marked by the isolation and conservatism of its social and cultural structures.

In the exploratory phase of our research, we heard testimonies showing that there were family groups whose members were divided between those who signed contracts and those who did not for fear of losing autonomy and control of their farms.

Among the surveyed rural landowners, there was some variation in the circumstances that involved adhering to contracts with energy companies. However, more than half (53.3 percent) said they did so for purely economic reasons, that is, because of the possibility of increasing 
and diversifying their income. At the Geribatu wind farm, which is part of the "Campos Neutrais" Wind Complex, the position of one of our interviewees was very clear:

It was an obvious decision for me... I can't earn in a year what I earn practically in a month with the wind... It's something extraordinary..., imagine, people are earning $R \$ 50$ or 60 thousand per month... what's the problem? (E-14)

For another of our interviewees the fundamental reason for adhering to the project was a desire for change and innovation in a region that was historically stagnant and depressed because of the strict dependence on incomes from farming:

Well, it is new, it is something new. When the wind farm started up in Santa Vitoria, the first property in my region joined up, Talagasso Farm... People didn't know much, there were many doubts (a 20-year lease). Our people are very conservative and very fearful. They thought, what if I lease my land and they don't pay me the rent?... What if they keep the field? What if they take over the park?... Well, I didn't have that fear, I told myself I would risk it. Some of my neighbours didn't want to participate, and today they regret it. (E-13)

The concrete reality brought with it the complexity of the processes that mark the social representation of reality in terms proposed by Moscovici (2009). Some positions showed optimism with the generation of renewable energy sources, as well as a positive self-image of farmers and the locations where wind farms were implemented.

We also asked producers about the problems they face in reconciling traditional activities (linked to agricultural production) and new activities linked to the generation of wind energy on their land. A large proportion (80 percent) of respondents said they had problems only in the initial stages of building the infrastructure in the face of the intense movement of machinery, equipment, and construction material in their areas:

During construction, there was a certain impact because there was a lot of movement of personnel, who left gates open... It didn't bother me because I already had an idea of what was going to happen. It was a problematic first year, but only during the construction. (E-2)

Following the propositions of Moscovici (2009) and Jodelet (1984), it should be noted that social representation is based on two processes: objectification and anchoring. The first deals with the materialization of knowledge in concrete objects, giving them an image and a structure. The second process (anchoring) refers to how the representation of the new object is incorporated into a set of pre-existing meanings and knowledge.

The farmer's narrative expresses his effort to become familiar with the unknown. In fact, what is perceived as a strange and disturbing object is later accepted (anchored) by the local actors, becoming something normal that, due to circumstances, ends up being incorporated into their mental landscape.

Some interviewees (mainly large rice producers) mentioned a certain degree of interference from the wind turbines in their work and agricultural practices, which was explained by the fact that their placement creates insurmountable physical obstacles to aerial application of pesticides. Some said they had to interrupt the cultivation of irrigated rice, but the decision was made without any major problems since the stable income provided throughout the year

${ }^{4}$ We have assigned the code " $\mathrm{E}$ " to identify the farmers interviewed, preserving, however, the confidentiality of the information and testimony offered during the field work. 
by the production of wind energy significantly increased their sources of economic income. In the words of one of these producers:

We no longer till the land for crops, we only carry out the tasks for raising livestock. It is difficult to use aircraft for chemical treatments... because people do not want to fly in the wind farm areas... there are many towers in the vicinity. (E-15)

There are even farmers who consider the reduction in the area of rice cultivation and in the use of aircraft for agricultural treatments to be positive. They consider rice to be an intensive crop that uses pesticides on a large scale and consumes a lot of water during much of the production cycle. The negative externalities of intensive rice production in southern Brazil are well known ${ }^{5}$.

The installation of the Wind Complex meant ensuring a safe and stable form of economic income. This is one of the aspects to which all of the interviewees' testimonies converged, as shown by some of their statements:

Look, I think that this was very good for us. We started to earn a monthly income, this was a big change, it was a benefit and a different way to manage the farm's performance because, in agriculture, you harvest today's plants in six months... That's how people lived. Today you have a monthly income, you can plan and make all kinds of investments, you count on what comes in every month. (E-15)

It's been good for me. I am still farming, just as / did before... / still have my maize plantations... and my animal feed... but this is only an aid. Before, I always needed to sell a cow to buy fertiliser. Now l leave the cow in the field and get the money from the wind farms to buy fertiliser, ... I leave it to sell it later in the good season [.... I don't need to rush to sell the animals. (E-6)

These testimonies showed a perception of reality centered on the direct benefits received by producers who joined the Wind Complex project and the importance it had in their daily lives. The first testimony is from a large farmer who was very satisfied with obtaining a secure and stable income. The second testimony is that of a small producer who, through this project, found a way to self-finance his agricultural activities, that is, a reproduction strategy that allows the maintenance and improvement of agricultural activities. However, reality shows that the difference between the economic situation of both producers is abysmal and, in the current circumstances, it only tends to increase.

Agricultural activity is affected by several factors, including inclement weather, fluctuations in agricultural prices, and changes in financing policies. Revenue generated by wind energy means an indirect way of financing agricultural and non-agricultural activities. In addition, it has guaranteed the possibility for owners to invest in their farms, either through the acquisition of new equipment and infrastructure or through the renovation of their homes and the improvement of the well-being of their families.

In addition to these elements incorporated into their daily lives, it was interesting to know whether rural owners have effectively developed the awareness that they are exercising a new social, economic and environmental function by participating in the process of generating clean and renewable energy. That is the purpose of the next section of this article.

${ }^{5}$ On this subject, see the study by Silva \& Sacco dos Anjos (2009). 


\section{The environmental functions of agriculture and rural areas}

Today the environmental exceptionality of agricultural activity is no longer admissible, and agriculture is perceived as a potentially polluting activity that can generate negative externalities. In the "Campos Neutrais" area, the agricultural modernization process brought with it unquestionable environmental impacts (degradation of aquifers, contamination of air, and soil). The use of aircraft for the application of pesticides has expanded enormously, putting the health of rural workers at risk, as well as the populations living in these spaces.

Article 225 of the Brazilian Constitution (Brasil, 1988) clearly states that everyone has the right to an ecologically balanced environment, as well as the duty to preserve it for present and future generations.

The protection of natural resources and biodiversity is one of the obligations of the State. Using and enjoying a healthy environment is embedded into what is known as "diffuse rights", in other words, a class of rights that belongs to all individuals, including those that have not yet been born. These rights are part of the intergenerational commitment recommended in the principles of sustainable development.

Our research confirmed the premise that most producers exercise their activities based on the logic of absolute rights over the natural resources in their domains. In this context, they minimize the environmental impacts of their activities. The positive image they build about themselves is evident in the exaltation of the virtues of agricultural production. These aspects had already been identified in studies carried out in the extreme south of Brazil, either in the production of irrigated rice (Silva \& Sacco dos Anjos, 2009) or in the production of soybeans (Nardini da Silva \& Sacco dos Anjos, 2020).

Our initial hypothesis was that the participation of farmers in the production of renewable energy could change the way they perceive environmental issues and assume the multifunctional character of agriculture and the rural world. We expected farmers to see their new social role as a window of opportunity and as a way of attributing a new source of legitimacy in society.

However, the information collected does not show evidence of substantial changes. One of our interviewees owns a 120-hectare property, where nine wind turbines were installed, generating a monthly income of approximately $R \$ 15,000$.

He is satisfied with the situation, but that did not stop him from criticizing the performance of environmental agencies concerning a farm he owns in another area, where he carried out unauthorized deforestation. His testimony can be seen as the reflection of a position antagonistic to state control.

He explains in his speech the right to demand that society pay the cost of maintaining wellpreserved areas of natural reserves. In other words, considers that the conservation of natural resources is almost a burden:

I have a property on the bank of the Pelotas River, which is environmental heritage, cultural... everything you can imagine... invaluable. I don't want to have someone value it for me... I have no rights, only obligations [...]. It's a lot of work! (E-1)

A crucial aspect of social representations is to understand the aspects underlying the behaviour of individuals who are inserted in pre-existing moral systems. In the case of farmers, social representations reflect ideological convictions of a mostly conservative social class. They build a positive view of themselves by describing their daily practices as completely harmless from the point of view of environmental impacts. To a large extent, the status of environmental exceptionality mentioned above remains unchanged, as can be seen in the testimony of a farmer who owns an 800-hectare farm: 
Look, I think we don't really do anything bad to the environment [...]. Of course, some jobs affect things, like streams, wetlands, and so on... (E-15)

The area where the Wind Complex is located is part of the Pampa Biome, a unique ecosystem that does not have leafy trees as in the case of the Atlantic Forest or the Brazilian Amazon. The interviewed farmers tend to circumscribe the issue of environmental impacts to the problem of deforestation and the elimination of vegetation cover. In this context, they minimize the losses arising from the irregular use of water resources, the intensive use of pesticides, the elimination of riparian forests, or the conservation of biodiversity. Conserving biodiversity, as we saw earlier, is one of the central axes of the concept of multifunctionality.

From the moment they started to earn income from the production of wind energy, many farmers stopped cultivating irrigated rice and even stopped renting their land to third parties for the same purpose. When the leasing contracts for rice cultivation end, soils are often degraded due to the use of herbicides and intensive mechanization.

In this context, the production of wind energy is perceived as a safe bet given the uncertainty and risk that rice cultivation entails. Income from wind power allows farmers to maintain their land capital without the detrimental effects of the intensive rice cultivation model. These examples can be seen through the various testimonies of the people interviewed, who praise the indirect environmental benefits of wind energy:

But the change makes up for it... the people who leased land to grow rice, are today rewarded by the income they receive from [wind] energy, which is much larger and, in addition, doesn't touch the land, you understand? The earth is protected, while agriculture causes soil degradation, you know? (E-15)

The Brazilian Institute of Environment and Renewable Natural Resources (IBAMA) is one of the most important bodies controlling environmental issues in Brazil, and also responsible for granting licences to large projects, including the "Campos Neutrais" Wind-power Complex. The IBAMA was no obstacle to the large public and private investments that culminated with the installation of wind turbines and all the adjacent structures.

However, the narrative of our interviewees reproduces a vision that minimizes the role of environmental agencies, understanding them as entities that hinder progress and reduce the autonomy of farmers. One of the interviewees, when asked about the reasons that made him sign the contract with wind companies, joyfully expressed the advantages of participating in this system. In his speech he mentions the possibility of conciliating energy generation with extensive livestock, but remains quite critical of IBAMA's actions:

We were pioneers... They were looking for investments. Now there are no more because the IBAMA has stopped it. But today, everybody wants to lease land for building wind farms. In the worst-case scenario, you continue with livestock as that generates you some income. (E-15)

The sale ${ }^{6}$ of the neutral fields wind complex took place in July 2020, a few months before the completion of this article. The sale transactions ${ }^{7}$ are related to Auction 01/2018, which took

\footnotetext{
${ }^{6}$ On this subject, see Centrais Elétricas Brasileiras S.A. (2020).

7 The company Omega Desenvolvimento de Energia, a member of the Tarpon Group and headquartered in the state of Minas Gerais, was created specifically with the objective of making possible the implementation phases of wind projects aimed exclusively at the generation of clean and renewable energy. She communicated the proposal to acquire $78 \%$ of the state's interest in the Santa Vitória do Palmar Complex (estimated capacity of $402 \mathrm{MW}$ ) for about 1 billion reais $(R \$)$, considering debt assumption of 577 million reais ( $\$$ ) and cash payment of 434.5 million reais ( $\$$ ). Omega also announced the proposal for a $99.99 \%$ stake in Eletrobras in the SPEs Hermenegildo I, Hermenegildo II and Chuí IX, which involved $R \$ 512.7$ million ( $\mathrm{R} \$$ ), of which $\mathrm{R} \$ 378.7$ million ( $\$$ ) in debt assumption, operations also disclosed in a Material Fact on its website. These wind farms reach $180.8 \mathrm{MW}$. All operations, amounting to approximately 1.5 billion reais $(R \$)$, were carried out with the authorization of the Administrative Council for Economic Defense (CADE).
} 
place on September 27, 2018, after approval by its Board of Directors and resolution by the General Shareholders' Meeting. The decision was made public through the communication of a "Material Fact" on the Eletrobras (Brazilian Power Centers) website. This operation involved the sale of its interests in 70 Special Purpose Entities (SPEs), out of a total of 178 SPEs that maintained in its structure ${ }^{8}$.

Some entities, such as the Rio Grande do Sul Engineers Union', indicate that the value of the operation reached only $17 \%$ of the value of the resources invested by the government. Such an organization expresses its discontent with the loss of state control in a sector considered strategic for the future of Brazil. For some of our interviewees, this change may threaten the continuity of the project, while for others it represents the melancholic end of the great transformations that were expected to be achieved in these regions of the country.

\section{Conclusions}

The winds of change and innovation indeed reached a forgotten region in the extreme south of Brazil. It is also true that the vision of our interviewees converges in the sense that cities like Santa Vitória do Palmar and Chuí, located on the borders of Brazil, have become visible on the map of Brazil. In addition, they consider that the "Campos Neutrais" Wind Complex has brought improvements to rural roads, as well as to personal and property security through continuous monitoring of the facilities. Another aspect that strengthens the optimism of the people involved in the Wind Complex is its effect on the valorisation of their land, explaining why some of the interviewed farmers expressed interest in expanding their properties in the expectation that more wind turbines could be installed in their areas.

In addition, changes in the landscape are evident in this extensive area of Brazil. Upon arriving in one of the cities in the area of the "Campos Neutrais" Wind Complex, the new gate greets the visitor with the following phrase: "The winds here bring energy to Brazil". From the farmers' point of view, the construction of this wind farm caused some discomfort due to the problems generated during the installation of the structures, but this discomfort soon disappeared when the farmers started to receive an advantageous, safe, and regular economic income.

Our research was developed with a view to the effects of a specific process of social and economic change, affecting not only the landscape and other tangible aspects but also the perceptions and attitudes of farmers. The arrival of the wind turbines meant an unprecedented change in the history of these places. However, it seems that these winds of change remain confined to the field of economic reality and have not altered the perceptions and attitudes of farmers on environmental-related issues.

For the conservative and suspicious farmers who inhabit this region of Brazil, wind energy projects initially seemed like a totally foreign subject, something with which they had to work very hard to get acquainted. However, the contact between the "new" and the "old" system of social representations produces a tension perceived in several statements. In this context, it can be concluded that, although the wind energy revenue has obtained a very positive reaction from the beneficiaries, it has not been strong enough to change the social representations of farmers regarding environmental issues.

Such producers are the direct beneficiaries of investments related to the production of renewable energies and the multifunctional pattern that emerges in rural areas. Despite this, most farmers in the "Campos Neutrais" region consider that the principles of sustainable

8 On this subject see Omega Geração (2020).

9 For more information see the website of the "Sul 21" in the references of this article (Sul 21, 2020). 
development, especially about the conservation of biodiversity, represent restrictions on the use of natural resources that are in their domains.

The dynamics created around these contracts represent an innovation in generating a safe, regular and stable source for the producers involved. In addition, the benefits are visible, as in the case of improved roads and increased property security due to the circulation of agents hired by the power generation company. However, these changes were not enough to alter the value system that guides their attitudes and behaviours in relation to the environmental issue, especially with regard to the performance of agents for the inspection and monitoring of biodiversity.

\section{References}

Abramovay, R. (2012). Muito além da economia verde. São Paulo: Editora Abril.

Agência Brasil. (2018). País sobe no ranking dos maiores produtores de energia eólica. Diário do Comércio. Retrieved in 2019, November 20, from https://dcomercio.com.br/categoria/ sustentabilidade/pais-sobe-no-ranking-dos-maiores-produtores-de-energia-eolica

Amaral, A. F. (1972). Os campos neutrais. Porto Alegre: Planus Artes Gráficas.

Atance, I., \& Tió, C. (2000). La multifuncionalidad de la agricultura: aspectos económicos e implicaciones sobre la política agraria. Revista Española de Estudios Agrosociales y Pesqueros, (189), 29-48. Retrieved in 2019, May 21, from https://ageconsearch.umn.edu/ record/.../pdf_reeap-r189_02.pdf

Bourdieu, P. (1972). Esquisse d'une théorie de la pratique, précédé de trois études d'éthnologie kabyle. Genève: Droz.

Brasil. (1988). Constituição Federal da República Federativa do Brasil, promulgada em 5 de outubro de 1988. Diário Oficial [da] República Federativa do Brasil(Seção 1, p. 1), Brasília.

Brasil. (2002). Lei n 10.438, de 26 de abril de 2002. Diário Oficial [da] República Federativa do Brasil (Seção 1, Edição Extra, p. 2), Brasília.

Brasil. Ministério de Minas e Energia. (2018). Energia limpa: Brasil registra 88\% de fontes renováveis na produção de energia em junho. Retrieved in 2019, March 22, from http://www.mme.gov. br/web/guest/pagina-inicial/outras-noticas/- /asset_publisher/32hLrOzMKwWb/content/ energia-limpa-brasil-registra-88-de-fontesrenovaveis-na-producao-de-energia-em-junho

Bueno, C., \& Aguilar Criado, E. (2003). Las expresiones locales de la globalización. Ciudad de México: CIESAS/Universidad Iberoamericana/Ed. Porrúa.

Burton, R. J. F. (2004). Seeing through the 'good farmer's' eyes: towards developing an understanding of the social symbolic value of 'productionist' behaviou. Sociologia Ruralis, 2(44), 195-215.

Cazella, A. A., Bonnal, P., \& Maluf, R. S. (2009). Agricultura familiar: multifuncionalidade e desenvolvimento territorial no Brasil. Rio de Janeiro: Mauad.

Centrais Elétricas Brasileiras, S. A. - Eletrobras. (2020). Retrieved in 2020, May 16, from https:// eletrobras.com/pt/ri/Paginas/Fatos-Relevantes.aspx

Daly, H. E. (1989). Economía, ecología yética: ensayos hacia una economía en estado estacionario. México: Fondo de Cultura Económica.

Díez Patier, E., \& Trueba Herranz, D. (2007). Evolución del uso del término multifuncionalidad en el contexto europeo. In J. A. Gómez-Limón, J. Barreiro Hurlé, E. Mármol \& C. Marcos (Eds.), La multifuncionalidad de la agricultura en España concepto, aspectos horizontales, 
cuantificación y casos prácticos (pp. 41-56). España: Ministerio de Agricultura, Alimentación y Medio Ambiente: Eumedia.

Dufour, A., Mauz, I., Remy, J., Bernard, C., Dobremez, C., Havet, A., Pauthenet, Y., Pluvinage, J., \& Tchakérian, E. (2007). Multifunctionality in agriculture and its agents: regional comparisons. Sociologia Ruralis, 47(4), 316-342.

Duveen, G. (2009). Poder das Ideias. In S. Moscovici (Ed.), Representações sociais: investigações em psicologia social (pp. 7-28). Petrópolis: Vozes.

Garrido Fernandez, F. E. (1999). Discursos y estrategias de los agricultores y sus organizaciones ante la introducción de métodos de agricultura sostenible en la Uunión Europea (Ph. D. tesis). Departamento de Economía, Sociología y Política Agraria, Universidad de Córdoba, Córdoba.

Georgescu-Roegen, N. (2012). O decrescimento: entropia, ecologia, economia. São Paulo: Senac São Paulo.

Jodelet, D. (1984). La representación social: fenómenos, concepto y teoría. In S. Moscovici (Ed.), Psicología social II: pensamiento y vida social: psicología social y problemas sociales (pp. 469-494). Barcelona: Ediciones Paidós.

Knickel, K., \& Henting, H. (2000). Methodological and conceptual issues in the study of multifunctionality and rural development. Sociologia Ruralis, 4(40), 512-528.

Lowe, P., Buller, H., \& Ward, N. (2002). etting the next agenda? British and French approaches to the second pillar of the Common Agricultural Policy. Journal of Rural Studies, 18(1), 1-17.

Marsden, T., \& Sonnino, R. (2008). Rural development and the regional state: denying multifunctional agriculture in the UK. Journal of Rural Studies, 24(4), 422-431.

Minayo, M. C. S. (1995). O conceito de representações sociais dentro da sociologia clássica. In P. A. Guareschi \& S. Jovchelovitch (Eds.), Textos em representações sociais (pp. 89-111). Petrópolis: Vozes.

Moscovici, S. (2009). Representações sociais. Petrópolis: Vozes.

Moyano, E. (2013). La reforma de la PAC o el tránsito hacia una política más territorial que sectorial. In E. Moyano (Ed.), Anuario: informe socioeconómico de la Agricultura Familiar em España (pp. 39-44). Madrid: Fundación de Estudios Rurales.

Moyano, E., \& Garrido Fernández, F. E. (2007). A propósito de la multifuncionalidad: discursos y políticas sobre agricultura y desarrollo rural. In J. A. Gómez-Limón, J. Barreiro Hurlé, E. Mármol \& C. Marcos (Eds.), La multifuncionalidad de la agricultura en España concepto, aspectos horizontales, cuantificación y casos prácticos (pp. 59-75). España: Ministerio de Agricultura, Alimentación y Medio Ambiente: Eumedia.

Moyano, E., \& Paniagua, A. (1998). Medio ambiente, desarrollo sostenible y escalas de sustentabilidade. Revista Espanola de Investigaciones Sociologicas, (83), 151-175.

Nardini da Silva, M., \& Sacco dos Anjos, F. (2020). A expansão da soja no município de Jaguarão/ RS: análise das percepções através da abordagem narrativa. Revista de Economia e Sociologia Rural, 58, 1-13.

Naylor, R., Hamilton-Webb, A., Little, R., \& Maye, D. (2018). The 'Good Farmer': Farmer Identities and the Control of Exotic Livestock Disease in England. Sociologia Ruralis, 58, 3-19.

Omega Geração. (2020). Retrieved in 2020, May 16, from http://www.omegageracao.com.br 
Pereira, V. C., \& Almeida, J. (2015). Relações entre a Atividade Carbonífera e o Rural em Candiota, RS, Brasil: análises sobre representações sociais em um contexto de dilemas sobre a energia. Revista de Economia e Sociologia Rural, 1(53), 127-142.

Reig-Martínez, E. R. (2007). Fundamentos económicos de la multifuncionalidad. In J. A. GómezLimón, J. Barreiro Hurlé, E. Mármol \& C. Marcos (Eds.), La multifuncionalidad de la agricultura en España concepto, aspectos horizontales, cuantificación y casos prácticos (pp. 19-39). España: Ministerio de Agricultura, Alimentación y Medio Ambiente: Eumedia.

Rémy, J. (2004). Um caminho sinuoso e semeado de espinhos. Os agricultores franceses: da especialização e intensificação da produção à multifuncionalidade e ao desenvolvimento sustentável. Estudos Sociedade e Agricultura, 12(1), 5-50.

Sacco dos Anjos, F., \& Caldas, N. V. (2012). Multifuncionalidade, turismo rural e pluriatividade: interfaces de um debate inacabado. Revista Espaço de Diálogo e Desconexão, 1(5), 1-23. Retrieved in 2019, July 7, from https://periodicos.fclar.unesp.br/redd/article/view/5335

Segrelles Serrano, J. A. (2007). El mito de la multifuncionalidad rural en américa latina. Actas Latinoamericanas de Varsovia, (29), 159-177. Retrieved in 2019, June 19, from https://web. ua.es/es/giecryal/documentos/documentos839/docs/mitomultifuncionalidad.pdf

Silva, M. A. D., \& Sacco dos Anjos, F. (2009). A dinâmica do uso da água e o discurso do grande produtor de arroz do extremo sul brasileiro frente ao novo marco institucional. Extensão Rural, 17, 25-46.

Silvasti, T. (2003). The cultural model of the good farmer and the environmental question in Finland. Agriculture and Human Values, (20), 143-150.

Verges, N. M. (2013). Multifuncionalidade rural: da teoria eficiente à prática ausente. GeoGraphos, 47(4), 359-382. Retrieved in 2019, July 15, from https://web.ua.es/es/revista-geographosgiecryal/documentos/nivea-massaretto.pdf

Wheeler, R. (2016). Reconciling windfarms with rural place identity: exploring residents' attitudes to existing sites. Sociologia Ruralis, 58, 3-19.

Yin, R. K. (2001). Estudo de caso: planejamento e métodos. Porto Alegre: Bookman. 